\title{
IAMJ
}

INTERNATIONAL

AYURVEDIC

MEDICAL JOURNAL

\section{COVID-19: A PROPHYLACTIC AND BASIC CURATIVE APPROACH THROUGH AYURVEDA}

\author{
Atal Singh Kushwaha ${ }^{1}$, Lajwanti Keswani ${ }^{2}$, Rajeev Shrivastav ${ }^{3}$ \\ ${ }^{1}$ M.D. Scholar 1ST Year, P.G. Dept. of Samhita Siddhant, PT. Khushilal Sharma Govt. Auto. Ayurved College \& \\ Institute Bhopal (M.P.), India \\ ${ }^{2}$ M.D. (Ayu) Reader and HOD, P.G. Dept. of Samhita Siddhant, PT. Khushilal Sharma Govt. Auto. Ayurved \\ College \& Institute Bhopal (M.P.), India \\ ${ }^{3}$ M.D. (Ayu.), Assistant Professor, P.G. Dept. OF Samhita Siddhant, PT. Khushilal Sharma Govt. Auto. Ayurved \\ College \& Institute Bhopal (M.P.), India
}

Corresponding Author: atal.kushwaha43@gmail.com

\section{https://doi.org/10.46607/iamj12p5042021}

(Published online: May 2021)

Open Access

(C) International Ayurvedic Medical Journal, India 2021

Article Received: 29/04/2021 - Peer Reviewed: 06/05/2021 - Accepted for Publication: 07/05/2021

Check for updates

\section{ABSTRACT}

The article reviews basic prophylactic and curative approaches mentioned in Ayurveda classics. As the current scenario is worst across the nation due to severe covid outrage it becomes merely important to explore and tell general society about the way of living through Ayurveda. Ayurveda is a science of life and not only a curative science, several basic principles are mentioned in it which should be followed by everyone like Dicharya, Ritucharya, Aahar Matra, Rasayan Sevan etc, these all can be the shielding protection from such infection to a great extent. Ayurveda doesn't give much stress on naming any particular disease rather it focuses mainly on understanding the pathogenesis through basic principles such as tri-sutra and treat it accordingly, this can frame a basic treatment approach also against this devil covid-19 which can be useful in treating mild cases easily and to a great extent. This paperwork in this regard.

Keywords: Covid-19, Dincharya, Ritucharya, Aahar Matra, Rasayan Sevan, Tri Sutra.

\section{INTRODUCTION}

The World Health Organisation (WHO) has declared the coronavirus disease 2019 (COVID-19) a pandem- ic. A global coordinated effort is needed to stop the further spread of the virus. A pandemic is defined as 
"occurring over a wide geographic area and affecting an exceptionally high proportion of the population." The last pandemic reported in the world was the H1N1 flu pandemic in 2009. On 31 December 2019, a cluster of cases of pneumonia of unknown cause, in the city of Wuhan, Hubei province in China, was reported to the World Health Organisation. In January 2020, a previously unknown new virus was identified, subsequently named the 2019 novel coronavirus. This novel coronavirus was named Coronavirus Disease 2019 (COVID-19) by WHO in February 2020. Coronaviruses got their name from the way that they look under a microscope. The virus consists of a core of genetic material surrounded by an envelope with protein spikes. This gives it the appearance of a crown. The word Corona means "crown" in Latin. Coronaviruses are a family of viruses that cause illness such as respiratory diseases or gastrointestinal diseases. Respiratory diseases can range from the common cold to more severe diseases- Severe Acute Respiratory Syndrome (SARS-CoV).

A novel corona virus (nCoV) is a new strain that has not been identified in humans previously. Once scientists determine exactly what coronavirus it is, they give it a name (as in the case of COVID-19, the virus causing it is SARS-CoV-2).

Hence by seeing the above and current scenario of covid outbreak a global coordinated effort is much needed and for this we are in strict need to search and bring out holistic facts from our classical Indian medicines like Ayurveda. Basically, Ayurveda Medicinal culture is not only for aiding disease but more for shielding the body from being contaminated. The prophylactic side of Ayurveda Stands primarily on three strong bases Dincharya, Ritucharya and Aahar i.e. daily routine from dusk to dawn, season wise transition in diet and regimen and lastly ideal dietary regimen as per changes in season. If these ideal facts can be drawn and made available for the general public than it could be very positive step in making people less prone to Covid in fact any infections outbreak.

The immunity of a person remains boosted through natural ways and methods not by modern social media activities like people are encouraged to seek out food rich in anti-oxidants and vit. $\mathrm{c}$ and so are advised to take onions, there is no such evidence that vitamin supplements will protect you from infections unless you are deficient. Unfortunately, the idea that pills, trendy superfoods or wellness habits can provide a shortcut to a healthy immune system is just a myth and not much more. The only way from decades ago and still too valid is to follow the facts of science which has been elaborated decades ago and is still valid and authentic.

\section{Review of literature -}

In present scenario being healthy and to maintain it can only be executed by following the facts mentioned in Ayurveda classics. Dincharya (day to day routine), Ritucharya (seasonal routine) and also dietary routine (aahar) i.e. what to take, when to take, how much to take even way of taking diets is also thoroughly mentioned. Present situation is demanding badly to explore these hidden facts and make it available for people so as to execute the healthy and immune society.

Ritu Anusar Shodhan i.e. detoxification as per seasons can play a vital role in maintaining health and also in avoiding diseases merely. Execution of vamankarm during Basant ritu (March-April) in normal and healthy peoples will definitely balance the doshas and will also make them less prone to certain diseases throughout the year specially kaphaj vikaras (shwas, kaas, udard, kandu, twacha vikaras, respiratory infections etc). In the same way execution of virechankarm during Sharadritu (September-October) and bastikarm during Varsha ritu (July-Aug) will definitely maintain the equilibrium status of doshas and thereby will help in avoiding various immunodeficient disorders.

Also, deliberate suppression of urges (vegdharan) regularly accounts for causing diseases and in our classics directly they had stated to avoid such deliberate suppression of urges to maintain the state of health. These urges are Mootra, Purisha, Shukra, Apaanvayu, Chardi, Nidra, Shyavthu, Kshudha, Pipasa etc.

So, nowadays people being involved in meetings regularly in hurry or urgency of their work often do 
so, but they don't realize and hence being doing so for so long gradually it results in disease manifestation collectively.

Also in present scenario its being very often that people are seeing very much obsessed and involved deeply in their work and lifestyle even to such an extent that they continue think even after office hours too and also in other hand the relaxation time with family is minimized badly which has caused their mind to continuously think without being relax for a while. And particularly this thing is being coded as vishad (anxiety, depression, overthinking) in our classics and is considered as most prior factor in aggravating disease as well as the most unwholesome element in making prone to any disease as well. Cha.su.25

Aahaar is again considered as the most prior tool for a person to stay and remain healthy. Exploring classics, we will come to know acharya charak quoted clearly the dravyas that should never be consumed such as valloor (dried meat), sushkshaak (dried vegetables) etc. And the current scenario is of doing things like that only like packed foods, packed vegetables, packed meat and everything and in china also the excess intake of such dried and contaminated meat products out raged covid 19 pandemic to the world. Also dravyas that are mentioned to consume regularly are somewhat swiped out from the modern dietics of present scenario such as shashtikshaalidhanya (a type of rice which takes time to prepare), saindhavlavan (a salt type which is being replaced by trendy iodine salt now a days), amalaki (aawla), madhu (pure honey) etc. After seeing this we can see that all these dietary items have been replaced by today's pizza, burger, megrita etc.

Also taking consequent meals without proper time intervals is also a big issue of concern now a days. Acharya vagbhatt mentioned 2-3yaam(6-9 hours) for a proper diet to digest and today frequently consumption of packed food, chips and all causes food to remain in undigested state for a long time which ultimately results in formation of aam (the partially digested food) which finally results in mandagni (vitiated digestive fire) and the same is considered as the vital and main cause of almost every disease clearly stated by Acharya vagbhatt (rogasarveapimandagno). Hence for the healthy state the above scenario needs to be idealized through Ayurveda.

Also, in vimansthan acharya charak mentioned very clearly about such a pandemic calamity by the name janpadodvansh. with time and vitiation of vaayu, jal, desh and kaal respectively causes the occurrence of pandemic like covid 19. There he told administration of panchkarma (the 5 detoxifying methods), rasayan (drugs that nourishes dhatu and multiplies it).

So as I mentioned above taking seasonal detoxification procedure properly will definitely help to be resistant for such situations like pratimarshnasya $(2$ drops of Sneha in each nostrils everyday), dhoomprapaan (inhalation of medicated dhoom like haridraetc) and vaman, virechan, bastikarmas mentioned above should be taken as described above.

Nidra (proper sleep) is also the most important and vital factor between healthy and diseased state. As per Ayurveda classics physiology of sleep is described as due to the fatigue state of manas and indriya respectively the process of nidra initiated. But in today's scenario due to the work load, late night working on laptops, movies , mobiles and excess use of such technologies, one avoids taking sound sleep irrespective of the fatigue state of manas and indriya and keep on working or watching movies which gradually becomes habitual and gets presented with various disorders and also disturbed metabolism of body. Hence as our science is the science of life and deals with every perspective of daily routine works too, daksh Samhita stated that atleast 6 hours (2 yaam) sleep is mandatory for an individual to survive in a healthy state and also sleeping hours for different conditions and age groups are also mentioned separately. And improper sleep induced various disorders are been mentioned in our classics which develops gradually and makes person prone for other communicable diseases also.

Rasayan-Rasayan is a unique concept of Ayurveda. Rasayan can be used in two aspects swasthashys wasthyarakshanam and aturasya vikar prashmanch (maintaining the health of healthy \& curing the diseased). Term rasayan means ras + ayan, rasa stands for nourishment and ayan stands for circulation. 
Hence by the administration of rasayan micro and macro circulation get improved and nourishment to each and every dhatu becomes easy. By the rasayan therapy one will get excellence of rasadi dhatu (enriches ras with nutrients) and hence through this one can attain longevity, freedom from disease, youthful age, excellence of posture, complexion and voice, respectability and brilliance.

\section{Some facts to form a basic curative approach} through classics-

Acharya Charak told a great and much meaningful quotation vyadhinamakushlo i.e. any disease whatever its name should never be judged or taken for treatment merely by its name.

Also, in very $1^{\text {st }}$ chapter of charak Samhita he mentioned that the whole Ayurveda both for a healthy or diseased person is based on trisutra (hetu, linga, aushadh). So as an Ayurveda scholar we should never think that how we can think of covid-19its not mentioned anywhere, how can we make any statement about etc, because our science does not treat or make an approach to any disease or condition by seeing its name label. We should ideally approach through hetuling-aushadh.

What's the cause/reason (hetu)?

What are the manifested symptoms/lakshansamucchay (linga)?

What should be the primary treatment approach as per the above two (aushadh)?

Another quotation is mentioned by Acharya Charak srotasamev samudaykatvam hi purushamicchanti i.e. shareer/body is nothing but the summation of srotas. These srotas poses their specific vitiating factors, symptoms and treatment modules respectively.

\section{DISCUSSION}

Hence a basic way of approaching can be made for not only covid-19 as well as for any type of disease. So, we can grossly analyses and can make a positive curative as well as prophylactic statement on covid-19 by just clubbing the above-mentioned facts of Acharya charak. So, the manifested symptomology/lakshansamucchay of covid-19 indicates the major vitiation of pranvahsrotas as most of them are the dushtilakshans of pranvahsrotas such as dry coughing, dyspnoea etc. Now as we seen above every srotas has its specific vitiating factors and treatment too. So, by ruling out the vitiating factors of pranvahsrotas from the vimansthan of charak Samhita we can get the probable causes of pranvahsrotodushti which can be widely used as the prophylactic measures by avoiding those causes (hetus). Just like

'Kshayat'- Avoid being so much fast and hurry in your daily routines like skipping proper meals due to intense busy schedule or office timings or taking a calculated diet in hurry, and also snacking in place of complete and proper diet which all collectively and persistently results in vitiation of dhatus and ultimately kshay (collapse).

'Sandharanat'- Avoid deliberate suppression of natural urges like micturition, sleep, stools, sternutation and importantly in contexts of pranvahsrotas(respiratory system)and covid-19 avoid suppression of breaths (commonly occurs after some heavy physical work or running or stairs passing).

'Raukshyat'- Avoid regular consuming of diets causing dryness (rukshta) in body such as legumes, dried vegetables (sushkshaak), also vihar (physical activities) like working or doing something beyond your strength regularly etc.

'Vyayamatkshuditashyach'- Avoid doing so much of exercise when you are hungry and most of us do the same early morning exercise without taking anything strictly avoided. Hence the above-mentioned causes can be used as prophylactic measures grossly for covid-19 and also for any disease of pranvahsrotas.

In the same way a gross treatment approach can also be drawn from the same, as every srotas has its specific line of treatment too. And so, treatment mentioned for pranvahsrotas by Acharya charak is shwash vat i.e. line of treatment of shwas vyadhi should be followed. Which is 'sarvesham bruhanam hi alpah' i.e. always go for bruhan aushadh avum annapan. Bruhan means nourishing, dhatu poshak, snigdh aahar avum aushadh. Which can include Madhur, snigdh, bruhanaushadh such as jeevniyagan, ashwgandha, guduchi, vasa, kantkari, gokshur etc. And also, continuous tak- 
ing of any pranvahsrotobalyarasayan and chyawanprash is the best in them.

Proper following of dincharya, ritucharya, aaharmatra and rasayan can play a shielding role at this time which is the most needful demand of the current scenario.

\section{CONCLUSION}

So hereby we can conclude that with the ideal classical approach a gross and primary thought process can be built against this devil covid-19 in both curative as well as prophylactic way. Society demands a classical shastrokt (classical) perspective form us and being young brigades and future graduates we all should reveal such facts hidden in our classics from years and yet still scientific as before. In this way by enlightening such curious and useful facts one can get a gross outlining towards SWASTH BHARAT.

\section{REFERENCES}

1. Pandit kashinath and Dr. gorakhnath Chaturvedi/ Charak Samhita of Agnivesh Charak- hindi commentary part $1 /$ Chaukhamba Bharti Academy/Varanasi reprint edition/ 2013/ sutra sthana chapter 1/ pg 08.

2. Pandit kashinath and DR. Gorakhnath Chaturvedi/ Charak Samhita of Agnivesh Charak hindi commentary part 1/ Chaukhamba Bharti Academy Varanasi/ 2013 / reprint edition/ sutra sthana chapter 28/ pg 572573.

3. Pandit kashinath and DR. Gorakhnath Chaturvedi/ Charak Samhita of Agnivesh Charak hindi commentary part 1/ Chaukhamba Bharti Academy Varanasi/ 2013 / reprint edition/ sutra sthana chapter 05/ pg 6-10.

4. Madhav Nidanam, Brahmanand Tripathi, reprint edition 2007, Chaukhamba prakashan Varanasi, pg.21-27.

5. Dr. P.S Byadgi/ Ayurveda vikriti vijnana and Roga vijnana/ Chaukhamba sansthana Varanasi/ 2011/ editor reprint / P.355.

6. Ayurlog: National Journal of Research in Ayurveda science - 2014;3(2):1-8.

7. Ayurveda vikriti vijnana and Roga vijnana, Dr. P.S Byadgi, editor reprint 2011, Chaukhamba Sansthana Varanasi; 2011: P.78.

\section{Source of Support: Nil Conflict of Interest: None Declared}

How to cite this URL: Atal Singh Kushwaha et al: Covid-19: A Prophylactic And Basic Curative Approach Through Ayurveda. International Ayurvedic Medical Journal \{online\} 2021 \{cited May, 2021\} Available from: http://www.iamj.in/posts/images/upload/2945 2949.pdf 